\title{
Environmental pollution in Vietnam: Challenges in management and protection
}

\author{
Ô nhiếm môi trương tại Việt Nam: Các thách thức trong quản lý và bảo vệ môi \\ truòng
}

Editorial

Chu, Thi Thu Ha*

Institute of Ecology and Biological Resources, Vietnam Academy of Science and Technology, 18 Hoang Quoc Viet, Cau Giay, Ha Noi, Vietnam

\begin{abstract}
Vietnam is facing big challenges in terms of environmental pollution caused by natural agents and anthropogenic activities. Environmental pollution in Vietnam is present in air, water and soil environments in many areas with contaminants including total suspended particles (TSP), organic substances, heavy metals, nutrients including ammonium, phosphate exceeding the allowable values of national standard. One of the most important causes of environmental pollution is the legal powers of environmental protection organizations, especially the environmental police force, not strong enough. In addition, the awareness of the people about environmental protection is very weak. Improving the system of laws on environmental protection, including sanctions that are strong enough to prevent violations, is of the most importance to enhance the effectiveness of environmental management and protection in Vietnam. On the other hand, educating people and even school children about environmental protection is a very meaningful activity to reduce the pressures and challenges of environmental management and protection in Vietnam.
\end{abstract}

Việt Nam đang phải đối mặt với nhũng thách lớn về ô nhiếm môi trương gây ra bởi các tác nhân tụ nhiên và các hoạt động của con người. Ô nhiêm môi trương ở Việt Nam biểu hiện ở cả môi trương không khí, nước và đất tại nhiều khu vưc với hàm lương các chất ô nhiễm gồm bui thô TSP. các chất hữu co', kim loại nặng, các chất dinh duõong gồm amoni, phosphat vuợt quá tiêu chuẩn cho phép. Một trong nhũng nguyên nhân quan trọng gây ô nhiếm môi truờng là sức mạnh pháp lý của các co quan tổ chức hoạt động trong linh vực môi truờng, đặc biệt là lực lượng cảnh sát môi truờng, chura đủ mạn. Bên cạnh đó, ý thức của người dân về giũ gìn bảo vệ môi truờng còn rất yếu. Việc hoàn thiện hệ thống luật pháp về bảo vệ môi trường bao gồm các chế tài đủ mạn để ngăn chạn các vi phạm là quan trọng hàng đầu nhằm tăng cương hiệu quả quản lý và bảo vệ môi truoòng ở Việt Nam. Mặt khác, giáo dục tuyên truyền ý thức cho người dân và thậm chí các học sinh trong trừng học về giữ gìn bảo vệ môi trương là hoạt động rất ý nghĩa nhằm giảm bớt các áp lực và thách thức trong quản lý và bảo vệ môi trường ở Việt Nam.

Keywords: environment, management, pollution, protection, Vietnam

\section{Introduction}

Environmental pollution is increasing and becomes serious situation in Vietnam, though Vietnamese institutions and sectors made great efforts in implementing environmental protection policies and laws. Pollution of water, air and soil as well as degradation of land are caused by both natural factors and anthropogenic activities. Climate changes, sea level rise, saline intrusion, acidification, flood, drought, desertification, leaching, erosion, are major natural factors causing environment pollution in large regions (MONRE, 2015). While anthropogenic activities including emission and discharge of untreated waste from industrial zones, mining zones, traditional trade villages cause heavily pollution for environment in separate regions (MONRE, 2017). In addition, transport, agriculture and deforestation also contribute to the pollution at urban, rural and forest areas. Environmental management and protection in Vietnam are encountering many challenges.

\section{Environmental pollution causes and state}


For the natural factors causing environmental pollution, it is required to have researches on forecasting the natural disasters as well as measures to prevent their effect. Vietnam had strategies for preventing and mitigating natural disasters through 2020 (Government of Vietnam, 2007). However, it is very difficult to avoid the loss caused by natural disasters. For the anthropogenic activities causing environmental pollution, there are different specific causes and effects.

Regarding air environment, in particular in urban areas, pollution pressure is mainly due to transportation, construction activities, operation of urban factories, residential activities, etc. In air pollution problems in urban Vietnam, dust pollution remains the most prominent problem. The proportion of monitoring samples containing total suspended particles (TSP) surpassing National Technical Regulation on Ambient Air Quality (QCVN $05: 2013 / \mathrm{BTNMT}$ ) is more than $80 \%$ of the monitoring sample in the year. $\mathrm{SO}_{2}, \mathrm{CO}$ gas pollutants were basically within the limits of national technical regulations, and $\mathrm{O}_{3}$ and $\mathrm{NO}_{2}$ concentrations were shown to be contaminated in recent years (MONRE, 2017).

At present, clean water is mainly supplied in urban areas. As of June $2016,82 \%$ of the urban population has access to clean water. The daily water use is 105 liters / person. Preliminary statistics show that the amount of water used for urban areas ranges from a few hundred to millions of cubic meters per year, of which about $40 \%$ of the water supplied to urban areas is extracted from groundwater (MONRE, 2017). Clean water in the rural areas is a matter of great concern in the current context that local people are facing with health risk because of high concentrations of pollutants. Some parameters such as arsenic (As), manganese $(\mathrm{Mn})$, ammonium $\left(\mathrm{NH}_{4}{ }^{+}\right)$(Tran Thi Mai, 2015), copper $(\mathrm{Cu})$, zinc ( $\mathrm{Zn})$ (Ta Thi Thao et al., 2015), iron (Fe), Mn, As, $\mathrm{NH}_{4}^{+}$(MONRE, 2017) in the groundwater using in daily life exceeded allowable values given in national technical regulation.

Water pollution is increasing and becomes serious situation in Vietnam. Surface water in some places is polluted, especially in urban areas, around industrial zones and craft villages. Some major sources of waste pollution in Vietnam include domestic, medical, industrial wastewater discharged to water bodies without being treated. Depending on the sources, wastewater contains some main pollutants such as suspended solids (SS), biochemical oxygen demand $\left(\mathrm{BOD}_{5}\right)$, nitrogen ammonium salts $\left(\mathrm{N}-\mathrm{NH}_{4}{ }^{+}\right)$, phosphate $\left(\mathrm{PO}_{4}{ }^{3-}\right)$, chloride $\left(\mathrm{Cl}^{-}\right)$and surfactant, inorganic components, microorganisms and other pathogenic microorganisms (MONRE, 2017). Along with water pollution, land pollution is becoming alarming. Especially in recent years, as the economy of Vietnam has been growing up to industrialization and modernization, many cities and towns are newly formed; the pollution situation is getting worse. Wastewater from factories and urban populations is polluting water source then the land is also heavily polluted. In large urban areas such as Ha Noi and Ho Chi Minh City, or areas concentrated industrial production and mining activities such as Thai Nguyen Province and Dong Nai Province, land pollution caused by waste from constructional, industrial activities are most visible, heavy metal content in the soil tends to increase. Mining activities have been causing a lot of negative impacts on the surrounding environment that leads to forest ecosystem change, agricultural land degradation and pollution. In addition, many organizations and individuals have not yet implemented the environmental rehabilitation and restoration obligations after the mine closure, reducing the effectiveness of land use, especially in the areas where many mines are located. And the consequences of environmental pollution from mining activities are so obvious. In addition, activities from traditional trade villages also caused heavy metal pollution in soil especially agricultural soil (Chu Thi Thu Ha, 2011; Cao Viet Ha, 2012; Pham Thi Thao Trang et al., 2016). Heavy metal polluted agricultural soil can lead to contaminated crops and food and cause health risk to local people (Phan Thi Phuong et al., 2016).

\section{Environmental management and protection}

\subsection{Shortcomings in environmental management and protection}

According to statistics from the Ministry of Justice, there are currently about 300 legal documents on environmental protection to regulate the behavior of individuals, organizations, economic activities, technical processes. However, the system of these documents is still incomplete, lacking in consistency, lack of details, stability is not high. The legal powers of environmental protection organizations, especially the environmental police force, are not strong enough, thus limiting the efficiency of activities of grasping the situation, detecting and preventing acts of violation on environment. The legal and sanctioning grounds for the types of acts of causing environmental pollution for crimes are still limited. Specifically, there are very few cases of environmental pollution that are subject to criminal treatment, while other handling measures such as forced removal from polluted areas, closure and suspension of operation of the facility.

Authorities at all levels are not fully aware of and concerned about environmental protection, which leads to the detachment of management and the lack of responsibility for environmental monitoring and control. In addition, one of the most important reasons that cause the environment pollution is weak awareness of people while the propaganda and education on environmental protection in society is still limited.

\subsection{Solutions for environmental management and protection}

One of the most important solutions for efficient management and protection of environment is that the State continues to perfect the system of laws on environmental protection, including sanctions to be strong enough to deter the violators. Besides, it is necessary to build synchronous environmental management system in factories and industrial zones according to international standards. Supervision is closely linked to a better environment. 
Furthermore, there should be programs promoting environmental education and propaganda to improve the awareness of people in the whole society about environmental protection. It is possible through the training activities such as throwing garbage in the right place, keeping hazardous waste separately and do not litter indiscriminately to create changes and raise awareness and sense of observance of environmental protection law for people. Adding garbage bins and public toilets in the tourist areas, large roads, densely populated areas like big cities is also very helpful. In the schools, educating children about environmental protection is very necessary that many developed countries have been implementing. In addition, intensifying the work to inspect and supervise the environment is required. Raising the professional capacity and capability of the contingent of officials in charge of environmental work and providing modern technical means to effectively serve these forces is expected as an efficient solution.

In short, the environmental pollution in Vietnam, though serious, can still be saved if everyone contributes their strengths and hands to protect for the green environment clean - beautiful and also for our own lives as well as the next generation.

\section{DAAD alumni workshop on "Environment and Natural Resources"}

The research studies on the situation of the environment at some areas of Vietnam and on pollution treatment solutions are helpful for the authorities in environmental management and protection. Reports on biodiversity and conservation of animals - plants, water resource management, development of renewable energy and bioenergy in particular are really essential basis for further activities making a greener environment, keeping the ecological balance and mitigating climate change effect. The DAAD Alumni workshop entitled "Environment and Natural Resources" is a precious opportunity for scientists and lecturers in Vietnam and in Germany to present and discuss together about research achievements on environment and natural resources.

As mentioned above, weak awareness of people is one of the most important factors causing environmental pollution and exhausting natural resources. Strengthening and renewing knowledge dissemination to improve people's awareness about the environment and natural resources protection are very necessary. Nearly 50 manuscripts of this workshop were selected to be published in the special issue (vol. 9 no. 1-5) of Journal of Vietnamese Environment. These papers of the workshop will contribute to convey a meaningful message about the need to efficiently manage and protect environment, conserve biodiversity, as well as promote research activities for better living environment and natural resources. The workshop will be also an opportunity for scientists from different countries to share experiences and solution to improve the quality and effectiveness of management and protection of environment and natural resources. The last but not least is an important expectation that through this workshop, a strong network of DAAD alumni - Vietnamese scientists who graduated in Germany will be established and reinforced. From that point, these scientists can have chance to establish collaborative relationships for proposing joining scientific research projects.

\section{References}

[1] Cao Viet Ha (2012) Evaluation for Lead and Copper Pollution in Agricultural Land in Van Lam District, Hung Yen Province. J. Sci. \& Devel. 10(4): 648-653 (in Vietnamese).

[2] Chu Thi Thu Ha (2011) Survey on heavy metals contaminated soils in Thai Nguyen and Hung Yen provinces in Northern Vietnam. J. Viet. Env. 1(1): 34-39.

[3] Government of Vietnam (2007) Decree number 172/2007/QĐ-TTg date 16/11/2007 of Vietnam Prime Minister on Approving the national strategy for prevention and mitigation of natural disasters through 2020 (in Vietnamese).

[4] MONRE - Ministry of Natural Resources and Environment (2015) National state of environment report in the period 2011-2015, 244 pp (in Vietnamese).

[5] MONRE - Ministry of Natural Resources and Environment (2017) National State of Environmental Report 2016 - Vietnam urban environment. Viet Nam Publishing house of Natural resources, Environment and Cartography, $168 \mathrm{pp}$ (in Vietnamese).

[6] Pham Thi Thao Trang; Phan Thi Phuong; Nguyen Khanh Linh; Nguyen Thi Kim Oanh; Ha Thi Thu Thuy; Ho Thi Oanh; Nguyen Kieu Bang Tam; Nguyen Thi My Trang; Do Thi Thu Trang; Nguyen Thi Hue; Vu Van Tu; Chu Thi Thu Ha (2016) Status of heavy metal $(\mathrm{Pb}, \mathrm{Cd})$ pollution in agricultural soil in Dong Mai lead recycling craft village in Hung Yen, Vietnam. J. Viet. Env. 8(5): 284-288.

[7] Phan Thi Phuong; Pham Thi Thao Trang; Nguyen Khanh Linh; Nguyen Thi Kim Oanh; Ha Thi Thu Thuy; Nguyen Kieu Bang Tam; Chu Thi Thu Ha (2016) The impacts of lead recycling activities to human health and environment in Dong Mai craft village, Hung Yen, Vietnam. J. Viet. Env. 8(5): 266270.

[8] QCVN 05:2013/BTNMT (2013) National Technical Regulation on Ambient Air Quality (in Vietnamese).

[9] Ta Thi Thao, Nguyen Manh Ha, Bui Duy Cam, Do Quang Trung (2015) Assessment of heavy metal contamination in underground water and accumulation of heavy metals in hair and nail of habitants from electric waste treatment places. Journal of Analytical Sciences 20(1): 111-119,129 (in Vietnamese).

[10] Tran Thi Mai (2015) Study of underground water physiochemical characteristics of two sections in Phuc Tho district, southern river - Hanoi contributing explanation of asenic pollution. Master thesis. VNU University of Science (in Vietnamese). 